\title{
Pengaruh Struktur Modal Terhadap Kinerja Perusahaan Berdasarkan Siklus Hidup Perusahaan
}

\author{
(The Influence of Capital Structure to The Company's Performance Based on The Life \\ Cycle of Companies)
}

\author{
Tia Ardianty Aulia*, Nining Ika Wahyuni, Indah Purnamawati \\ Jurusan Akuntansi, Fakultas Ekonomi dan Bisni, Universitas Jember (UNEJ) \\ Jln. Kalimantan 37, Jember 68121 \\ E-mail: tdiandz@gmail.com
}

\begin{abstract}
Abstrak
Penelitian ini bertujuan untuk meneliti pengaruh struktur modal terhadap kinerja perusahaan berdasarkan siklus hidup perusahaan. Populasi dalam penelitian ini adalah seluruh perusahaan manufaktur yang terdaftar pada Bursa Efek Indonesia (BEI) pada tahun 2011-2015. Pengambilan sampel dilakukan dengan metode purposive sampling, yaitu dengan menggelompokkan perusahaan ke dalam tahapan siklus hidup berdasarkan rata-rata pertumbuhan penjualan. Sampel dalam penelitian ini sebanyak 98 perusahaan. Penelitian ini menggunakan sumber data sekunder yaitu laporan keuangan perusahaan manufaktur pada tahun 2011-1015. Data yang digunakan antara lain penjualan, hutang, ekuitas, aset dan laba setelah pajak. Metode analisis data menggunakan Statistik Deskriptif, Uji Asumsi Klasik, Analisis Regresi Berganda, Uji Hipotesis yang terdiri dari Uji t, Uji F, dan Koefisien Determinasi (R Square). Hasil penelitian menujukkan bahwa struktur modal pada tahap start up, growth, dan mature berpengaruh positif signifikan terhadap kinerja perusahaan. Stuktur modal pada setiap tahapan siklus hidup perusahaan tersebut berbeda-beda, semakin besar struktur modal maka kinerja perusahaan semakin meningkat.
\end{abstract}

Kata Kunci: Struktur Modal, Kinerja Perusahan, Siklus Hidup Perusahaan, manufaktur

\begin{abstract}
This research aims to examine the effect of capital structure to the company's performance based on the life cycle. The population in this study are all manufacturing companies listed on the Indonesia Stock Exchange (BEI) in 2011-2015. Sampling by using purposive sampling method, that is by grouping companies into life cycle stages based on the average sales growth. The sample in this study as many as 98 companies. This research uses secondary data that the financial statements of companies manufacturing the years 2011-2015 were obtained in the Indonesia Stock Exchange. The data used include sales, debt, equity, assets and profit after tax.Methods of data analysis using Descriptive Statistics, Clasiccal Assumption Test, Regression Methods, and Hypothesis Test consisted of $\mathrm{t}$ Test, F Test and Coefficient of Determinatio (R Square). The results showed that the capital structure at start up, growth, and mature have a significant positive effect on company performance. The capital structure at each stage of the company life cycle is different, the greater the capital structure then the company's performance is increasing.
\end{abstract}

Keywords: Capital Structure, Company Performance, Company Life Cycle, manufactur

\section{Pendahuluan}

Saat ini perkembangan dunia bisnis menciptakan persaingan yang semakin ketat dan kompetitif antar perusahaan. Situasi ekonomi ini menyebabkan perusahaan diharuskan memiliki kinerja yang baik untuk mempertahankan keberlangsungan hidupnya dan meningkatkan pertumbuhan perusaahan. Berdirinya suatu perusahaan tentu memiliki tujuan yang ingin dicapai. Tujuan utama perusahaan adalah memaksimalkan laba (profit oriented) dan mensejahterakan para pemegang saham (stakeholder). Tujuan perusahaan tersebut dapat terwujud melalui kinerja perusahaan (firm performance) yang baik. Kinerja perusahaan memperlihatkan kemampuan perusahaan untuk memberikan keuntungan dari aset, ekuitas, maupun hutang (Fachrudin, 2011) Peningkatan sumber daya perusaahan merupakan salah satu upaya untuk menciptakan kinerja perusahaan yang semakin baik. Namun, untuk meningkatkan sumber dayanya, perusahaan memerlukan dana yang besar yang digunakan untuk membiayai investasi yang dilakukan perusahaan. Keputusan mengenai investasi (investment) dan pendanaan (financing) dilakukan oleh manajer perusahaan. Pendanaan tersebut diperoleh dari sumber pendanaan internal (internal financing) maupun pendanaan eksternal (external financing). Sumber pendanaan internal berasal dari laba yang ditahan dan penyusutan (depresiasi), sedangkan sumber dana eksternal berasal dari pinjaman/ hutang (debt financing) dan modal sendiri (equity financing).

Sumber pendanaan yang digunakan untuk membiayai investasi berkaitan dengan struktur modal. Struktur modal merupakan pendanaan ekuitas dan hutang dalam suatu perusahaan (Brealey et al, 2006). Menurut Hafsah dan Sari (2015), struktur modal adalah perimbangan atau perbandingan antara modal asing (jangka panjang) dan modal sendiri. Penentuan struktur modal menjadi masalah yang penting bagi perusahaan karena kinerja perusahaan ditentukan dari baik dan buruknya keputusan manajer terhadap struktur modal. Perusahaan yang struktur modalnya optimal maka menghasilkan tingkat pengembalian yang optimal pula, sehingga tidak hanya perusahaan yang mendapat keuntungan, tetapi pemegang saham juga akan mendapatkan keuntungan tersebut. Sedangkan, bila stuktur modalnya tidak optimal maka akan timbul biaya modal yang terlalu besar sehingga biaya hutang semakin besar.

\footnotetext{
* Corresponding Author
} 
Disamping itu, ada kajian struktur modal yang dikaitkan dengan siklus hidup perusahaan. Menurut Frielinghaus et al (2005), struktur modal berkaitan dengan siklus hidup (life cycle) perusahaan. Kebutuhan rasio hutang akan berbedabeda sesuai dengan tahapan hidup perusahaan karena kebutuhan pendanaan dapat berubah sesuai dengan kondisi perusahaan. Siklus hidup perusahaan menjelaskan bahwa perusahaan berkembang dan berpindah dari tahapan satu ke tahapan lainnya. Roring dan Ronni (2014) menyatakan siklus hidup perusahaan terdiri dari empat tahap, yaitu tahap awal (start-up), tahap pertumbuhan (growth), tahap dewasa (mature), dan tahap penurunan (decline). Tahap-tahap dari siklus tersebut ditentukan dari dua hal yaitu volume penjualan (pertumbuhan) dan laba rugi perusahaan yang berpengaruh terhadap kinerja perusahaan.

Pemahaman tentang siklus hidup diperlukan perusahaan dalam menganalisis kebutuhan pendanaan. Sumber pendanaan mencerminkan pada tahap apa perusahaan itu berada. Bagi perusahaan dengan tingkat pertumbuhan penjualan dan laba yang tinggi kencendrungan penggunaan hutang sebagai sumber dana eksternal yang lebih besar dibandingkan perusahaan-perusahaan yang tingkat pertumbuhannya penjualanya rendah (Savitri, 2014). Weston dan Brigham (1981) menyatakan bahwa perusahaan yang baru berdiri akan menggunakan modal dari pemilik (modal internal). Jika perusahaan telah melewati tahap awal, perusahaan akan mencari sumber dana lain seperti hutang atau kredit bank.

Dalam pecking order theory menjelaskan terjadinya urutan prioritas pendanaan yang dimulai dari pendanaan internal, kemudian hutang, dan pilihan terakhir adalah modal saham. Menurut Sinthayani dkk (2015), perusahaan memilih menggunakan internal financing lebih dahulu untuk membiayai operasinya. Kemudian, apabila diperlukan pendanaan dari luar maka perusahaan akan memulai dengan menerbitkan sekuritas paling aman, yaitu obligasi.Penerbitan saham menjadi pilihan terakhir perusahaan jika pendanaan operasi belum mencukupi. Menurut Restiyowati (2014), dalam signaling theory, perusahaan dengan prospek menguntungkan akan mencoba menghindari penjualan saham dan mengusahakan modal baru dengan cara lain, seperti penggunaan hutang. Investor baru beranggapan bahwa perusahaan yang menerbitkan saham kesulitan mendapatkan sumber pendanaan dari hutang karena kinerja perusahaan yang kurang baik. Dalam trade-off theory, dengan pendanaan hutang maka perusahaan dapat memperoleh manfaat dari penghematan pajak. Hutang membuat perusahaan memiliki kewajiban untuk membayar beban bunga setiap periode. Semakin tinggi beban bunga maka jumlah laba kena pajak semakin rendah, sehingga jumlah pajak yang harus dibayarkan perusahaan menjadi lebih rendah. Dengan

Dalam tahapan siklus hidup, pendanaan perusahaan akan berbeda-beda sesuai dengan kondisi perusahaan (Frielinghaus et al, 2005). Menurut Damodaran (2001), perusahaan dalam tahap start up memperoleh sumber dana dari ekuitas pemilik dan mungkin sedikit utang bank, karena baru berdiri maka hambatannya adalah sulit mendapatkan dana. Selain itu, tahap ini ditandai dengan pertumbuhan penjualan cenderung lambat dan juga memperoleh laba yang relatif kecil. Pada tahap growth, perusahaan mulai memenuhi kebutuhan pasar dan pertumbuhannya cepat karena pemenuhan kebutuhan pasar lebih baik daripada kompetisi sehingga laba meningkat cepat (Quinn dan Cameron, 1983). Menurut Damodaran (2001), pada tahap mature, laba dan arus kas akan berlanjut untuk meningkat dengan cepat. Perusahaan akan menggunakan hutang bank dari obligasi untuk mebiayai investasinya. Menurut Savitri (2014), perusahaan dengan penjualan meningkat akan membutuhkan dana besar untuk meningkatkan kegiatan operasionalnya yang tidak tercukupi dengan pendanaan internal, sehingga membutuhkan sumber dana eksternal. Peningkatan kegiatan operasional tentu akan meningkatkan pendapatan perusahaan, sehingga perusahaan dapat memperoleh laba. Dengan memperoleh laba yang maksimal maka perusahaan dikatakan memiliki kinerja perusahaan yang baik dan tujuan perusahaan dapat terpenuhi.

Berdasarkan landasan teori dan penemuan empiris tersebut maka dihasilkan hipotesis sebagai berikut.

$\mathrm{H}_{1}$ : struktur modal pada tahap start up berpengaruh terhadap kinerja perusahaan

$\mathrm{H}_{2}$ : struktur modal pada tahap growth berpengaruh terhadap kinerja perusahaan

$\mathrm{H}_{3}$ : struktur modal pada tahap mature berpengaruh terhadap kinerja perusahaan

Berdasarkan latar belakang tersebut maka rumusan masalah dalam penelitian ini adalah :

1. Apakah struktur modal pada tahap pengenalan (start-up) berpengaruh terhadap kinerja perusahaan?

2. Apakah struktur modal pada tahap pertumbuhan (growth) berpengaruh terhadap kinerja perusahaan?

3. Apakah struktur modal pada tahap dewasa (mature) berpengaruh terhadap kinerja perusahaan?

Sesuai dengan rumusan masalah di atas, maka tujuan penelitian ini adalah:

1. Untuk mengetahui apakah struktur modal pada tahap pengenalan (start-up) berpengaruh terhadap kinerja perusahaan.

2.Untuk mengetahui apakah struktur modal pada tahap pertumbuhan (growth) berpengaruh terhadap kinerja perusahaan.

3. Untuk mengetahui apakah struktur modal pada tahap dewasa (mature) berpengaruh terhadap kinerja perusahaan.

\section{Metode}

\section{Rancangan dan Desain Penelitian}

Jenis penelitian ini adalah penelitian kuantitatif. Dalam penelitian ini dilakukan analisis deskriptif statistik, uji asumsi klasik, analisis regresi linier berganda, dan uji hipotesis. Analisis dilakukan dengan menjelaskan hubungan variabel independen terhadap variabel dependen.

\section{Jenis dan Sumber Data}

Sumber data dalam penelitian ini diperoleh dari data sekunder yaitu laporan keuangan perusahaan manufaktur pada tahun 2011-2015 yang terdaftar di bursa efek indonesia. Data yang digunakan antara lain penjualan, hutang, ekuitas, aset dan laba setelah pajak.

\section{Populasi dan Sampel}

Populasi dalam penelitian ini adalah seluruh perusahaan manufaktur yang terdaftar pada Bursa Efek Indonesia (BEI) pada tahun 2011-2015. Pengambilan sampel dilakukan dengan teknik nonprobability sampling yaitu dengan metode 
purposive sampling. Sampel dalam penelitian ini sebanyak 98 perusahaan. Dimana pengelompokan ini didasarkan pada pertumbuhan penjualan (Agrawal dan Gup (1996) dalam Arifin, 2009).

Tabel 1.1 Tingkat Pertumbuhan Penjualan dala Tahapan Siklus hidup Perusahaan

\begin{tabular}{cc}
\hline Siklus Hidup & Rata-rata pertumbuhan penjualan \\
\hline Start up & $>50 \%$ \\
Growth & $10 \%-49,9 \%$ \\
Mature & $0 \%-9,9 \%$ \\
Decline & $<0 \%$ \\
\hline
\end{tabular}

\section{Metode Analisis Data}

Untuk menguji hipotesis bahwa struktur modal pada tahapan siklus hidup start up, growth, dan mature berpengaruh terhadap kinerja perusahaan digunakan analisis regresi linier berganda. Persamaan regresi dalam penelitian ini adalah :

ROA $=\mathrm{a}+\mathrm{b}_{1}$ DER $*$ Start up $+\mathrm{b}_{2}$ DER $*$ Growth + $\mathrm{b}_{3}$ DER*Mature $+\mathrm{e}$

Keterangan:

ROA : Return on Assets

$\mathrm{b}_{1}, \mathrm{~b}_{2}, \mathrm{~b}_{3} \quad$ : koefisien regresi

Dummy siklus hidup perusahaan ( $k-1)$

Start up : 1 jika siklus hidup perusahaan pada tahap start up dan 0 untuk lainnya

Growth : 1 jika siklus hidup perusahaan pada tahap growth dan 0 untuk lainnya

Mature : 1 jika siklus hidup perusahaan pada tahap mature dan 0 untuk lainnya

Decline : kategori dasar

e : eror

Terhadap persamaan diatas dilakukan uji asumsi klasik yaitu uji normalitas dengan menggunakan uji kolmogorov smirnov, uji autokolerasi dengan menggunakan uji durbin watson, uji heterokedasitas dengan menggunakan uji glejser, uji multikolinieritas dengan menggunakan nilai tolerance dan Variance Inflanation Factor (VIF).

\section{Hasil dan Pembahasan}

\section{Hasil}

\section{Statistik Deskriptif}

Tabel 4.2 Hasil Statistik Deskriptif

\begin{tabular}{ccccc}
\hline $\begin{array}{c}\text { Variabel } \\
\text { Penelitian }\end{array}$ & Min & Max & Mean & $\begin{array}{c}\text { Standar } \\
\text { Deviasai }\end{array}$ \\
\hline DER Start up & $-31,78$ & 70,83 & 4,6676 & 2,990029 \\
DER Growth & $-9,45$ & 11,25 & 1,3215 & 1,77681 \\
DER Mature & $-30,60$ & 27,98 & 1,0107 & 3,96388 \\
ROA & $-0,25$ & 0,66 & 0,0613 & 0,09 \\
\hline Lampiran: 5 & & & &
\end{tabular}

Berdasarkan hasil analisis pada Tabel 4.2 dapat diketahui bahwa untuk variabel DER Start-up menunjukkan nilai ratarata (mean) sebesar 1,3418. Nilai terendah variabel DER Start-up sebesar $-31,78$ dan nilai tertinggi 70,83. Standar deviasi sebesar 2,990029. Hal ini berarti nilai standar deviasi yang mendekati nilai rata-rata (mean) dan ukuran penyebaran data yang semakin kecil.

Berdasarkan hasil analisis pada Tabel 4.2 dapat diketahui bahwa untuk variabel DER Growth menunjukkan nilai ratarata (mean) sebesar 1,3215. Nilai terendah variabel DER Growth sebesar $-9,45$ dan nilai tertinggi 11,25. Standar deviasi sebesar 1,77681. Hal ini berarti nilai standar deviasi yang mendekati nilai rata-rata (mean) dan ukuran penyebaran data yang semakin kecil.

Berdasarkan hasil analisis pada Tabel 4.2 dapat diketahui bahwa untuk variabel DER Mature menunjukkan nilai ratarata (mean) sebesar 1,0107. Nilai terendah variabel DER Mature sebesar -30,60 dan nilai tertinggi 27,98. Standar deviasi sebesar 2,990029. Hal ini berarti nilai standar deviasi mendekati nilai rata-rata (mean) dan ukuran penyebaran data semakin kecil.

Nilai rata-rata (mean) untuk variabel ROA sebesar 0,0613 . Nilai terendah variabel ROA sebesar $-0,25$ dan nilai tertinggi 0,66 Standar deviasi sebesar 0,09943. Hal ini berarti nilai standar deviasi mendekati nilai rata-rata (mean) dan ukuran penyebaran data semakin kecil.

Dalam hasil deskriptif statistik nilai DER minimal bernilai negatif, hal ini disebabkan karena total ekuitas negatif pada beberapa perusahaan. Ekuitas negatif diakibatkan oleh akumulasi saldo laba ditahan bernilai negatif (akumulasi defisit).

\section{Uji Asumsi Klasik \\ a. Uji Normalitas}

Tabel 4.3 Hasil Uji Normalitas

\begin{tabular}{ccc}
\hline Variabel & $\begin{array}{c}\text { Nilai Kolmogorov } \\
\text { Smirnov }\end{array}$ & Keterangan \\
\hline DER Start up & 0,138 & Berdistribusi normal \\
\hline DER Growth & 0,119 & Berdistribusi normal \\
\hline DER Mature & 0,192 & Berdistribusi normal \\
\hline ROA & 0,200 & Berdistribusi normal
\end{tabular}

Lampiran: 6

Berdasarkan Tabel 4.3 hasil pengujian pada tabel tersebut, dapat diketahui bahwa variabel DER Start up memiliki nilai probabilitas atau signifikansi sebesar 0,138 variabel DER Growth memiliki nilai probabilitas atau signifikansi sebesar 0,119 , variabel DER Mature memiliki nilai probabilitas atau signifikansi sebesar 0,192, dan variabel ROA memiliki nilai probabilitas atau signifikansi sebesar 0,200. Nilai tersebut lebih besar dari 0,05. Sehingga, dapat dinyatakan bahwa data dalam penelitian ini berdistribusi normal. 


\section{b. Uji Autokorelasi}

Tabel 4.4 Hasil Uji Autokorelasi

\begin{tabular}{ccc}
\hline Model & $\begin{array}{c}\text { Nilai Durbin- } \\
\text { Watson }\end{array}$ & Keterangan \\
\hline 1 & 1,830 & $\begin{array}{c}\text { Tidak terjadi } \\
\text { autokorelasi }\end{array}$ \\
\hline
\end{tabular}

Lampiran: 6

Berdasarkan hasil pengujian pada tabel 4.4 dapat diketahui bahwa nilai Durbin-Watson sebesar 1,830. Nilai tersebut Angka Durbin-Watson diantara $\mathrm{Du}<\mathrm{DW}<4$-Du. Sehingga dapat dinyatakan bahwa data dalam penelitian ini terjadi autokorelasi.

\section{c. Uji Heterokedasitas}

Tabel 4.5 Hasil Uji Heterokedasitas

\begin{tabular}{ccc}
\hline Variabel & Sig & Keterangan \\
\hline DER Start up & 0,926 & Tidak terjadi heterokedasitas \\
DER Growth & 0,612 & Tidak terjadi heterokedasitas \\
DER Mature & 0,198 & Tidak terjadi heterokedasitas
\end{tabular}

\section{Lampiran: 6}

Berdasarkan tabel 4.5 dapat diketahui bahwa nilai signifikansi masing-masing variabel lebih besar dari 0,05 , sehingga dari hasil tersebut dapat diketahui bahwa tidak terjadi heterokesdatisitas dari persamaan yang diuji.

\section{d. Uji Multikolinieritas}

Tabel 4.6 Hasil Uji Multikolinieritas

\begin{tabular}{|c|c|c|c|}
\hline \multirow{2}{*}{ Varabel } & Collinearity & Statistics & \multirow{2}{*}{ Keterangan } \\
\hline & Tolerance & VIF & \\
\hline DER Start up & 0,850 & 1,176 & $\begin{array}{c}\text { Tidak terjadi } \\
\text { multikolinieritas }\end{array}$ \\
\hline DER Growth & 0,735 & 1,360 & $\begin{array}{c}\text { Tidak terjadi } \\
\text { multikolinieritas }\end{array}$ \\
\hline DER Mature & 0,843 & 1,187 & $\begin{array}{c}\text { Tidak terjadi } \\
\text { multikolinieritas }\end{array}$ \\
\hline
\end{tabular}

\section{Lampiran: 6}

Berdasarkan hasil analisis Collinearity Statistics yang dapat dilihat pada tabel 4.6 diketahui bahwa model tidak terjadi multikolinieritas. Hal tersebut ditandai dengan nilai VIF dari masing-masing variabel kurang dari 10 dan nilai tolerance lebih dari 0,10 .

\section{Analisis Regresi Linier Berganda}

Tabel 4.7 Hasil Analisis Linier Berganda

\begin{tabular}{cccc}
\hline Variabel & $\begin{array}{c}\text { Koefisien } \\
\text { Regresi }\end{array}$ & Sig. & Keterangan \\
\hline Konstan & 0,008 & - & - \\
DER Start up & 0,050 & 0,047 & Signifikan \\
DER Growth & 0,113 & 0,001 & Signifikan \\
DER Mature & 0,285 & 0,000 & Signifikan \\
\hline
\end{tabular}

\section{Lampiran: 7}

Berdasarkan Tabel 4.7 hasil tersebut dapat diperoleh persamaan regersi linier berganda sebagai berikut:

$\mathrm{ROA}=0,008+0,050($ DER Start up $)+0,113$ (DER Growth) $+0,285$ (DER Mature) $+e$

\section{a. Nilai Konstanta}

Dari persamaan diatas didapatkan nilai konstanta sebesar 0,008 yang berarti bahwa jika nilai dari variabel DER sama dengan nol, maka ROA adalah sebesar konstanta 0,008.

\section{b.DER Start up}

Nilai koefisien dari variabel DER Start up adalah bernilai Positif 0,050 dan nilai signifikansi 0,047 yang berarti bahwa setiap kenaikan satu satuan variabel tersebut, akan meningkatkan ROA sebesar 0,050 .

\section{c.DER Growth}

Nilai koefisien dari variabel DER Growth adalah bernilai Positif 0,113 dan nilai signifikansi 0,001 yang berarti bahwa setiap kenaikan satu satuan variabel tersebut, akan meningkatkan ROA sebesar 0,113.

\section{d. DER Mature}

Nilai koefisien dari variabel DER Mature adalah bernilai Positif 0,285 dan nilai signifikansi 0,000 yang berarti bahwa setiap kenaikan satu satuan variabel tersebut, akan meningkatkan ROA sebesar 0,285.

\section{Uji Hipotesis}

a. Uji t (parsial)

Tabel 4.8 Hasil Uji t

\begin{tabular}{cc}
\hline Variabel & Sig. \\
\hline DER Start up & 0,047 \\
DER Growth & 0,001 \\
DER Mature & 0,000 \\
\hline
\end{tabular}

Lampiran: 8 
Berdasarkan tabel tersebut dapat diketahui besar dari pengaruh masing-masing variabel independen terhadap variabel dependen sebagai berikut :

\section{Pengaruh variabel DER Start up terhadap variabel ROA}

Berdasarkan Tabel 4.8 dapat dilihat bahwa tingkat probabilitas $(\alpha)$ adalah 0,047 , Hal ini berarti DER Start up berpengaruh signifikan terhadap ROA, nilai probabilitas < 0,05 maka terbukti kebenarannya $\left(\mathrm{H}_{1}\right.$ diterima $)$.

\section{Pengaruh variabel DER Growth terhadap variabel ROA}

Berdasarkan Tabel 4.8 dapat dilihat bahwa tingkat probabilitas $(\alpha)$ adalah 0,001 , Hal ini berarti DER Growth berpengaruh signifikan terhadap ROA, nilai probabilitas < 0,05 maka terbukti kebenarannya $\left(\mathrm{H}_{2}\right.$ diterima).

\section{Pengaruh variabel DER Growth terhadap variabel ROA}

Berdasarkan Tabel 4.8 dapat dilihat bahwa tingkat probabilitas $(\alpha)$ adalah 0,000 , Hal ini berarti DER Growth berpengaruh signifikan terhadap ROA, nilai probabilitas < 0,05 maka terbukti kebenarannya $\left(\mathrm{H}_{3}\right.$ diterima).

\section{b. Uji F}

Tabel 4.9 Hasil Uji F

\begin{tabular}{ccccccc}
\hline & Model & $\begin{array}{c}\text { Sum of } \\
\text { Square }\end{array}$ & df & $\begin{array}{c}\text { Mean } \\
\text { Square }\end{array}$ & F & Sig. \\
\hline 1 & Regresion & 8,701 & 3 & 2,175 & 31,492 & $0,000^{\mathrm{b}}$ \\
& Residual & 12,433 & 180 & 0,069 & & \\
& Total & 21,134 & 183 & & & \\
& & &
\end{tabular}

Lampiran: 8

Berdasarkan hasil perhitungan uji $\mathrm{F}$ yang terlihat pada tabel 4.9 diperoleh nilai Sig. sebesar 0,000 lebih kecil dari nilai 0,05 (Sig. < 0,05), maka dapat disimpulkan bahwa model yang digunakan untuk menguji pengaruh struktur modal terhadap kinerja perusahaan adalah model yang layak.

\section{c. Uji Koefisien Determinasi $\left(\mathbf{R}^{\mathbf{2}}\right)$}

Tabel 4.10 Hasil Uji Koefisien Determinasi $\left(\mathrm{R}^{2}\right)$

\begin{tabular}{lllll}
\hline Model & R & R Square & $\begin{array}{l}\text { Adjusted } \\
\text { Square }\end{array}$ & $\begin{array}{r}\text { R Std. Error of } \\
\text { The Estimate }\end{array}$ \\
\hline 1 & $0,642^{\mathrm{a}}$ & 0,412 & 0,399 & 0,26281673
\end{tabular}

Lampiran: 8

Berdasarkan hasil Adjusted $R$ Square pada tabel 4.10 terlihat bahwa nilai Adjusted R Square sebesar 0,399 atau 39,9\%. Hal ini menunjukkan bahwa 39,9\% variabel Kinerja Perusahaan dapat dijelaskan oleh Struktur Modal pada tahap start up, growt, dan mature, dan sisanya yaitu $61,1 \%$ dijelaskan oleh variabel-variabel lain di luar persamaan.

\section{Pembahasan}

\section{Struktur Modal Pada Tahap Start Up Berpengaruh Terhadap Kinerja Perusahaan}

Variabel struktur modal pada tahap start up berpengaruh positif signifikan terhadap variabel kinerja perusahaan, hal ini ditunjukkan oleh koefisien regresi sebesar 0,050 dan nilai signifikasi yang berada di bawah $0,05(0,047<0,05)$ sehingga sesuai dengan hipotesis pertama yang menyatakan bahwa Struktur Modal Pada Tahap Start Up Berpengaruh Terhadap Kinerja Perusahaan. Dengan demikian hipotesis pertama pada penelitian ini diterima $\left(\mathrm{H}_{1}\right.$ diterima). Struktur modal pada tahap start up berpengaruh positif signifikan terhadap kinerja perusahaan, hal ini menyatakan setiap kenaikan satu satuan variabel tersebut, akan meningkatkan ROA sebesar 0,05. Dengan diterimanya hipotesis pertama $\left(\mathrm{H}_{1}\right)$, maka penelitian ini menolak hasil penelitian Arifin (2009) yang menyatakan bahwa struktur modal yang didasarkan pada siklus hidup perusahaan tidak berpengaruh terhadap kinerja perusahaan baik kinerja profitabilitas maupun kinerja saham.

Dalam tahap start up, penggunaan struktur modal pada tahap ini lebih kecil dibandingan pada tahap lainnya, hal ini dapat terlihat dari koefisien regresi start up yaitu sebesar 0,050 , sedangkan koefisien regresi pada tahap growth sebesar 0,113 dan tahap mature sebesar 0,285. Pecking order theory menjelaskan terjadinya urutan prioritas pendanaan yang dimulai dari pendanaan internal, kemudian hutang, dan pilihan terakhir adalah modal saham. Menurut Sinthayani dkk (2015), perusahaan memilih menggunakan internal financing lebih dahulu untuk membiayai operasinya. Menurut Quinn dan Cameron (1983), pada tahap pengenalan start-up, perusahaan digambarkan seperti anak kecil yang baru berjalan. Perusahaan baru diperkenalkan sebagai bisnis kecil, sebagian besar cepat gagal karena eksekutif tidak memahami kebutuhan pasar dan tidak tahu bagaimana memenuhi kebutuhan tersebut. Tetapi jika perusahaan tersebut sukses maka penjualan akan bertambah. Menurut Damodaran (2001), perusahaan dalam tahap start up memperoleh sumber dana dari ekuitas pemilik dan mungkin sedikit utang bank, karena baru berdiri maka hambatannya adalah sulit mendapatkan dana. Selain itu, tahap ini ditandai juga dengan laba yang relatif kecil.

Hasil penelitian ini konsisten dengan penelitian oleh Marusya dan Magantar (2016) yang menyatakan Debt to Equity Ratio (DER) berpengaruh positif signifikan terhadap Return on Assets (ROA).

\section{Struktur Modal Pada Tahap Growth Berpengaruh Terhadap Kinerja Perusahaan}

Variabel struktur modal pada tahap growth berpengaruh positif signifikan terhadap variabel kinerja perusahaan, hal ini ditunjukkan oleh koefisien regresi sebesar 0,113 dan nilai signifikasi yang berada di bawah $0,05(0,01<0,05)$ sehingga sesuai dengan hipotesis kedua yang menyatakan bahwa Struktur Modal Pada Tahap Growth Berpengaruh Terhadap Kinerja Perusahaan. Dengan demikian hipotesis kedua pada penelitian ini diterima $\left(\mathrm{H}_{2}\right.$ diterima). Struktur modal pada tahap growth berpengaruh positif signifikan terhadap kinerja perusahaan, hal ini menyatakan setiap kenaikan satu satuan variabel tersebut, akan meningkatkan ROA sebesar 0,113.Dengan diterimanya hipotesis kedua $\left(\mathrm{H}_{2}\right)$, maka penelitian ini menolak hasil penelitian Arifin (2009) yang menyatakan bahwa struktur modal yang didasarkan pada siklus hidup perusahaan tidak berpengaruh terhadap kinerja perusahaan baik kinerja profitabilitas maupun kinerja saham. Namun, dalam penelitian Arifin (2009), ketika pengujian 
dikelompokkan dalam sampel ukuran perusahaan, keputusan struktur modal berpengaruh pada kinerja perusahaan.

Pada tahap growth, struktur modal perusahaan meningkat dari tahap start up, sehingga menunjukkan pada tahap ini kinerja perusahaan lebih baik dibandingkan pada tahap start up. Menurut Quinn dan Cameron (1983), pada tahap growth, perusahaan digambarkan seperti anak remaja. Perusahaan mulai memenuhi kebutuhan pasar dan pertumbuhannya cepat karena pemenuhan kebutuhan pasar lebih baik daripada kompetisi sehingga laba meningkat cepat. Brigham dan Gapenski dalam Savitri (2014) menyatakan bahwa perusahaan yang memiliki tingkat pertumbuhan yang tinggi cenderung membutuhkan dana dari sumber eksternal yang lebih besar.

Hasil penelitian ini konsisten dengan penelitian oleh Marusya dan Magantar (2016) yang menyatakan Debt to Equity Ratio (DER) berpengaruh positif signifikan terhadap Return on Assets (ROA).

\section{Struktur Modal Pada Tahap Mature Berpengah Terhadap Kinerja Perusahaan}

Variabel struktur modal pada tahap mature berpengaruh positif signifikan terhadap variabel kinerja perusahaan, hal ini ditunjukkan oleh koefisien regresi sebesar 0,285 dan nilai signifikasi yang berada di bawah $0,05(0,00<0,05)$ sehingga sesuai dengan hipotesis pertama yang menyatakan bahwa Struktur Modal Pada Tahap Start Up Berpengaruh Terhadap Kinerja Perusahaan. Dengan demikian hipotesis ketiga pada penelitian ini diterima $\left(\mathrm{H}_{3}\right.$ diterima $)$. Struktur modal pada tahap mature berpengaruh positif signifikan terhadap kinerja perusahaan, hal ini menyatakan setiap kenaikan satu satuan variabel tersebut, akan meningkatkan ROA sebesar 0,285. Dengan diterimanya hipotesis ketiga $\left(\mathrm{H}_{3}\right)$, maka penelitian ini menolak hasil penelitian Arifin (2009) yang menyatakan bahwa struktur modal yang didasarkan pada siklus hidup perusahaan tidak berpengaruh terhadap kinerja perusahaan baik kinerja profitabilitas maupun kinerja saham. Selain itu, dalam penelitian Arifin (2009), struktur modal menurun pada tahap mature.

Dalam penelitian ini, penggunaan struktur modal perusahaan pada tahap mature lebih besar dibandingkan pada tahap lainnya. Nilai koefisien regresi pada tahap mature sebesar 0,285 lebih besar dibandingkan pada tahap-tahap sebelumnya. Pada tahap mature, perusahaan digambarkan sebagai orang dewasa. Menurut Damodaran (2001), pada tahap mature, laba dan arus kas akan berlanjut untuk meningkat dengan cepat. Perusahaan akan menggunakan hutang bank dari obligasi untuk mebiayai investasinya. Dalam trade-off theory, hutang membuat perusahaan memiliki kewajiban untuk membayar beban bunga setiap periode. Semakin tinggi beban bunga maka jumlah laba kena pajak semakin rendah, sehingga jumlah pajak yang harus dibayarkan perusahaan menjadi lebih rendah. Dengan demikian, laba bersih perusahaan menjadi lebih tinggi. Sehingga, dengan memperoleh laba yang maksimal maka perusahaan dikatakan memiliki kinerja perusahaan yang baik dan tujuan perusahaan dapat terpenuhi.
Hasil penelitian ini konsisten dengan penelitian oleh Marusya dan Magantar (2016) yang menyatakan Debt to Equity Ratio (DER) berpengaruh positif signifikan terhadap Return on Assets (ROA).

\section{Simpulan}

Berdasarkan rumusan masalah dan tujuan penelitian, yaitu untuk mengetahui pengaruh struktur modal terhadap kinerja perusahaan berdasarkan siklus hidup perusahaan, maka sesuai dengan hasil perhitungan analisis data, penelitian ini dapat disimpulkan bahwa:

a. Struktur modal pada tahap start up berpengaruh terhadap kinerja perusahaan dan menunjukkan hubungan yang positif signifikan/

b. Struktur modal pada tahap growth berpengaruh terhadap kinerja perusahaan dan menunjukkan hubungan yang positif signifikan.

c. Struktur modal pada tahap mature berpengaruh terhadap kinerja perusahaan dan menunjukkan hubungan yang positif signifikan.

Struktur modal semakin meningkat seiring dengan pekembangan perusahaan. Hal itu disebabkan karena semakin berkembangnya perusahaan, maka perusahaan itu membutuhkan dana yang besar dalam kegiatan operasionalnya. Peningkatan kegiatan operasional akan meningkatkan pendapatan perusahaan yaitu dengan perolehan laba. Semakin besar laba yang didapatkan maka perusahaan dapat memenuhi tujuan umum perusahaan. Dengan demikian maka perusahaan dikatakan memiliki kinerja yang baik.

\section{Referensi}

Arifin, Zaenal. 2009. Pengaruh Daur Hidup Perusahaan terhadap Keputusan Struktur Modal. Jurnal Media Riset Bisnis \& Manajemen, Vol.9, No.2, pp.113-134.

Brealey, Myers, dan Marcus. 2006. Dasar-dasar Manajemen Keuangan Perusahaan. Edisi Kelima. Jilid satu. Jakarta Erlangga.

Damodaran. 2001. Corporate Finance : Theory and Practice. New York: John Wiley and Sons.

Fachrudin, K.A. 2011. Analisis Pengaruh Struktur Modal, Ukuran Perusahaan, dan Agency Cost Terhadap Kinerja Perusahaan. Jurnal Akuntansi dan Keuangan, Vol.13, No.1:37-46.

Frielinghaus, B. Mostert, dan C. Firer. 2005. Capital Structure and the Firm's Stage. Graduate School of Business University of Cape Town.

Hafsah dan Sri Suta S. 2015. Analisis Struktur Modal Terhadap Kinerja Keuangan pada Perusahaan Properti dan Real Estate yang Terdaftar di BEI. Jurnal Riset Akuntansi dan Bisnis, Vol. 15, No. 1.

Marusya, Pontroring dan Mariam Magantar. 2016. Pengaruh Sruktur Modal Terhadap Profitabilitas pada Perusahaan Tobacco Manufacturers yang Terdaftar di Bursa Efek Indonesi (BEI) Periode 208-2015. Jurnal Berkala Ilmiah Efisiensi, Vol.16, No.3

Quinn, Robert E. dan Kim Cameron. 1983. Organizational Life Cycle and Shifting Criteria of Effectiveness: Some Preliminary Evidence. Management Science, 29(1), 33-51.

Restiyowati, Idayu. 2014 Faktor-faktor yang Mempengaruhi Struktur Modal Perusahaan Property di Bursa Efek Indonesia. Jurnal dan Ilmu Riset Manajemen, Vol.3, No.2.

Roring, R. dan Sautma Ronni. 2014. Pengaruh Biaya Agensi dan Siklus Hidup Perusahaan terhadap Kebijakan Dividen pada Industri Manufaktur. Jurnal Finesta, Vol.2, No.2:63-67.

Savitri, Enni. 2014. Analisis Pengaruh Leverage dan Siklus Hidup terhadap Manajemen Laba pada Perusahaan Real Estate dan Property yang Terdaftar di Bursa Efek Indonesia. Jurnal Akuntansi, Vol.3, No.1. 
Sinthayani dan Sedana. 2015. Determinan Struktur Modal (Studi Komparatif pada Manufacture Multinational Corporation dan Domestic Corporation di BEI). E-Jurnal Manajemen Unud, Vol.4, No.10.
Weston dan Brigham. 1981. Essential of Managerial Finance. $5^{\text {th }}$ edition, The Dryden Press, New York 